\title{
IONTOVÁ VÝMĚNA V POČÁTEČNÍCH STÁDIÍCH INTERAKCE ŽIVEC-VODA
}

\author{
lon-exchange during initial stages of feldspar - water interaction \\ Markéta Camfrlová, Karel Vybíhal, Jiří Faimon \\ Ústav geologických věd, PřF MU, Kotlářská 267/2, 61137 Brno; e-mail: marketa.camfrlova@gmail.com
}

Key words: feldspar dissolution; ion exchange; alkali metals $/ \mathrm{H}^{+}$ratio; dissolution; PHREEQC simulation

\begin{abstract}
The sample of perthitic alkali feldspar (62.5 wt. \% of KAlSi $\mathrm{O}_{8}$ and $37.5 \mathrm{wt}$. \% of albite, $\mathrm{Na}_{0,996} \mathrm{Ca}_{0,004} A_{1,004} \mathrm{Si}_{2,996} \mathrm{O}_{8}$ ) was dissolved in a special stirred batch reactor (polyethylene vessel of 5 liter volume situated horizontally and rotating at few rotations per hour). The reactor was opened to atmosphere ( $\left.\log P_{\mathrm{CO} 2} \sim-3.5\right)$ through the mouth at the vessel axis. During the experiment, $p H$ was monitored by $\mathrm{pH}$-meter with combined glass electrode. Solutions were analyzed for $\mathrm{Si}$, Al (spectrophotometry), $\mathrm{K}, \mathrm{Na}$ (flame AAS), and $\mathrm{Ca}$ (ICP-OES). The results showed a fast preferential leaching of alkaline cations with respect to both Al and Si during the early stages of experiment that was diminishing during more advanced stages of the experiment. The released cations exceeded the consumed $H^{+}$ions by the range of two up to four magnitudes. The preponderance of cations over $H^{+}$ions was especially apparent during few initial days, when the buffering by atmospheric $\mathrm{CO}_{2}$ was insufficient. Simulation of the process by the PHREEQC code covering the $\mathrm{CO}_{2}$ buffering indicated that system feldspar-water- $\mathrm{CO}_{2(g)}$ was evolving near the equilibrium in open system during the period after 5 th day of the experiment. The results suggested that the mechanism of feldspar dissolution during the initial stages of the process does not correspond to a simple ion exchange and that it is more complicated.
\end{abstract}

\section{Úvod}

Interakce živec-voda je významný geologický proces na povrchu planety. Chemické zvětrávaní živcủ se podílí na modifikaci přirodnich vod a na vzniku sedimentů a půd. Ovlivňuje globální cykly $\mathrm{CO}_{2}$ díky spotř̌ebě $\mathrm{CO}_{2}$ $\mathrm{z}$ atmosféry (Appelo - Postma 2005). Existuje všeobecně přijímaný názor, že $\mathrm{v}$ počátečních stádiích rozpouštění živců dochází k iontové výměně kationtů alkálií $\left(\mathrm{Na}^{+}, \mathrm{Ca}^{+}\right.$, $\mathrm{K}^{+}$) na povrchu minerálu za $\mathrm{H}^{+}$ionty $\mathrm{v}$ roztoku. Při iontové výměně dochází $\mathrm{k}$ nahrazení kationtů alkálií vodíkovými ionty $\mathrm{z}$ roztoku, kdy jeden ekvivalent alkalického kovu je vyměněn za 1 mol vodíkových iontů (Chou - Wollast 1985). Důsledkem přednostního vyloužení kationtů alkálií z minerálu do roztoku a jejich nahrazením vodíkovými ionty je vznik alterované vrstvy na povrchu minerálu s odlišným chemickým složením (Hellmann et al. 1997) podle rovnice:

$$
\mathrm{NaAlSi}_{3} \mathrm{O}_{8}+\mathrm{H}^{+}=\mathrm{Na}^{+}+\mathrm{HAlSi}_{3} \mathrm{O}_{8}^{*}
$$

kde produkt s hvězdičkou je součástí připovrchové „vrstvy“ minerálu.

Cílem práce bylo přispět $\mathrm{k}$ lepšímu pochopení mechanismu procesů $\mathrm{v}$ systému živec-voda.

\section{Materiál a metody}

Vzorky živce pro experimenty byly odebrány z pegmatitu lokality Věžná. Byly očištěny od viditelných stop ostatních minerálů (slídy, křemen) a rozdrceny $\mathrm{v}$ drtičì. Kovové zbytky $\mathrm{z}$ drcení byly odstraněny pomocí permanentního magnetu. Zrnitost vzorku byla vymezena přesíváním vzorku ve vodné suspenzi. Sítováním byla získána zrnitostní frakce 63-800 $\mu \mathrm{m}$. Takto získaný vzorek živce byl opakovaně proplachován deionizovanou vodou, sušen při pokojové teplotě a použit pro experimenty. Minerální složení bylo určeno chemickou analyzou (elektronová mikrosonda CAMECA SX 100) jako perthitický živec tvořený $62,5 \mathrm{hm}$. \% draselného živce $\left(\mathrm{KAlSi}_{3} \mathrm{O}_{8}\right)$ a 37,5 $\mathrm{hm}$. \% albitu $\left(\mathrm{Na}_{0,996} \mathrm{Ca}_{0,004} \mathrm{Al}_{1,004} \mathrm{Si}_{2,996} \mathrm{O}_{8}\right)$. Celkové poměry vybraných prvkù ve vzorku jsou $(\mathrm{K}+\mathrm{Na}+\mathrm{Ca}) / \mathrm{Al} \sim 0,97$, $(\mathrm{K}+\mathrm{Na}+\mathrm{Ca}) / \mathrm{Si} \sim 0,33$ a Al/Si $\sim 0,34$. Rozměry odmíšených fází (perthitů) se pohybovaly v rozmezí $1-70 \mu \mathrm{m}$. Na základě úvah o rozměru a tvaru zrn byla odhadnuta specifická povrchová plocha vzorku na $0,02 \mathrm{~m}^{2} / \mathrm{g}$ (tzv. geometrická povrchová plocha). Povrchové plochy jednotlivých minerálů byly vypočteny z poměru molárních objemů draselného živce a albitu a váhového množství vzorku použitého pro experiment: celkový povrch albitu činil $2,91 \mathrm{~m}^{2}$ a draselného živce $5,09 \mathrm{~m}^{2}$. Pro experimenty byl použit vsádkový míchaný reaktor. Reaktor představovala pomalu se otáčející polyethylenová nádoba o objemu 5 litrů, umístěná „naležato" na dvou horizontálních válcích poháněných elektromotorem (několik otáček za hodinu). Atmosférický $\mathrm{CO}_{2}$ se volně vyměňoval s roztokem otvorem $\mathrm{v}$ ose nádoby. $\mathrm{V}$ reaktoru bylo rozpouštěno $400 \mathrm{~g}$ vzorku živce v 1,5 litru deionizované vody. $V$ časových intervalech 1-4 dny byly z reaktoru odebírány vzorky roztoku o objemu $15 \mathrm{ml}$. Vzorkování probíhalo celkově 14 dní. Získaný roztok byl odstředován při otáčkách $13000 \mathrm{rpm}$ po dobu 15 minut tak, aby byly odstraněny př́padné prachové částice (artefakt př́ípravy vzorků minerálů).

pH bylo měřeno př́strojem HANNA HI 8314 s kombinovanou skleněnou elektrodou Theta 90 (Crytur) prŕmo v reaktoru. Koncentrace $\mathrm{Si}$ a Al byly určeny spektrofotometricky ( $\mathrm{Si}$ - metodou molybdenové modři, 
Truesdale - Smith 1976, Al - metodou pyrokatecholové violeti, Dougan - Wilson 1974). Koncentrace K a Na byly stanoveny metodou AAS (plamenová verze, Solaar M5), koncentrace Ca metodou ICP-OES (Unicam PU 7000). Modelování bylo provedeno pomocí programu PHREEQC for Windows (Parkhurst - Appelo 1999).

\section{Výsledky a jejich diskuze}

Vývoj pH, koncentrací alkalických kovů a kovů alkalických zemin (AK\&KAZ), a koncentrací Si a Al $\mathrm{v}$ průběhu experimentu je na obrázku 1. Hodnota $\mathrm{pH}$ se $\mathrm{v}$ počátcích interakce postupně zvyšovala $\mathrm{z}$ počátečních 5,2 na konečných 7,65 (s lokálním poklesem na 7,18 v 8. dnu experimentu). V počátečních stádií experimentu došlo k rychlému nárůstu koncentrací $\mathrm{AK} \& \mathrm{KAZ}$ na $(0,4-1,0) \cdot 10^{-4} \mathrm{~mol} / \mathrm{l}$. V dalších stádiích koncentrace AK\&KAZ v podstatě stagnovaly s výkyvy do $5 \cdot 10^{-5} \mathrm{~mol} / \mathrm{l}$. U koncentrací Na lze po počátečním nárůstu vystopovat zřetelný pokles. Koncentrace Si během experimentu se více méně plynule zvyšovala až na $1,8 \cdot 10^{-4} \mathrm{~mol} / \mathrm{l}$. Koncentrace $\mathrm{Al}$ sledovala podobný trend s přibližně polovičními koncentracemi, avšak s většími výkyvy - patrné jsou poklesy v 6. a 8. dnu experimentu.

Vývoj poměrů AK\&KAZ ke hliníku a křemíku a vývoj změn ekvivalentů $A K \& K A Z$ a vodíkových iontů $\mathrm{H}^{+}$ během experimentu je demonstrován na obrázku 2. Jednak je zde vidět převaha $A K \& K A Z$ nad hliníkem a křemíkem v počátečních stádiích experimentu (obr. 2a) a jednak nepoměr mezi př́růstky ekvivalentů $\mathrm{AK} \& \mathrm{KAZ} \mathrm{a} \mathrm{H}^{+}$iontů (obr. 2b). Molární poměr $(\mathrm{Na}+\mathrm{K}+\mathrm{Ca}) / \mathrm{Al}$ se během experimentu snižoval od 17,1 do 2,1 , poměr $(\mathrm{Na}+\mathrm{K}+\mathrm{Ca}) / \mathrm{Si}$

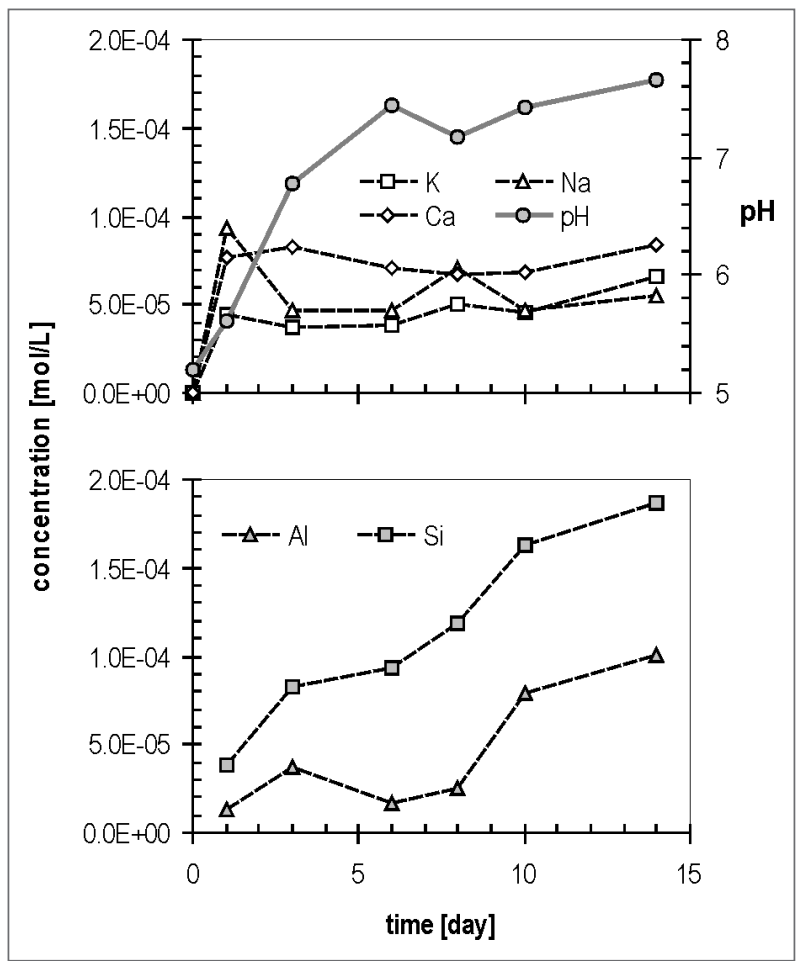

Obr. 1: Vývoj koncentrací (a) K, Na, Ca, pH a (b) Si, Alv roztoku při experimentálním rozpouštění živců.

Fig. 1: Evolution of aqueous concentrations of $\mathrm{K}, \mathrm{Na}, \mathrm{Ca}, \mathrm{pH}$ (a) and $\mathrm{Si}, \mathrm{Al}(\mathrm{b})$ at experimental feldspar dissolution.

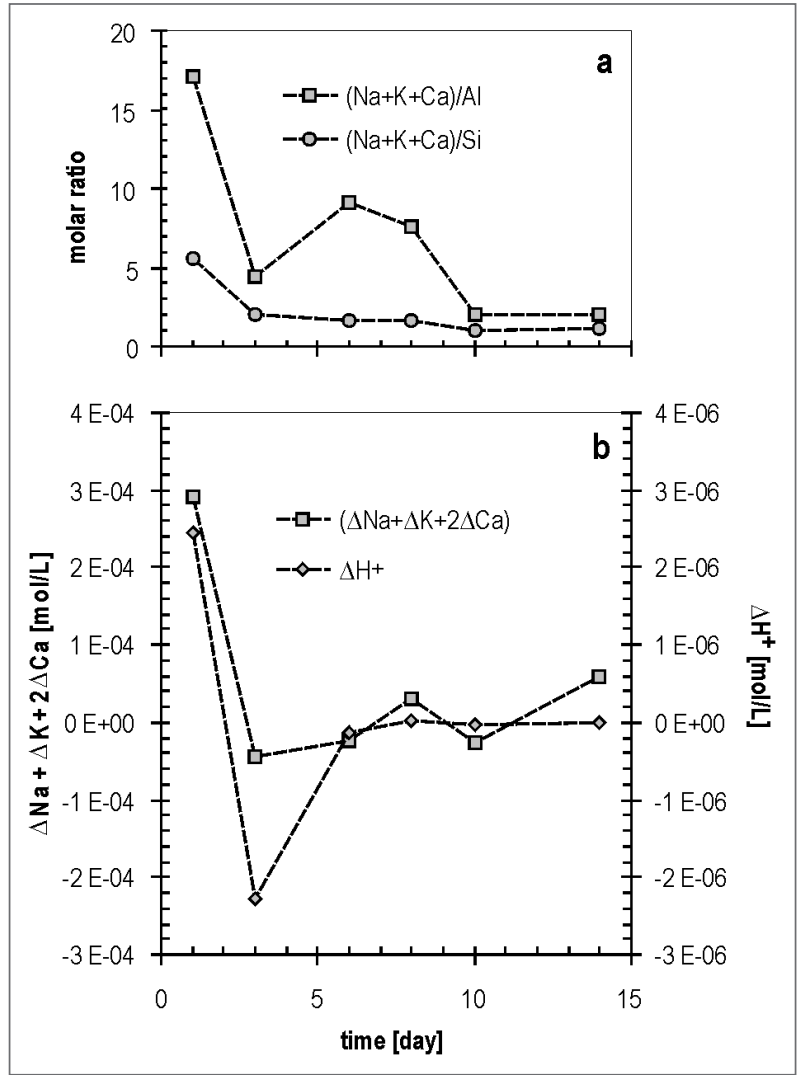

Obr. 2: Vývoj stechiometrií sledovaných složek v roztoku během experimentu: (a) Vývoj poměrů alkálií ku Al resp. Si; (b) vývoj změn ekvivalentů alkálií a $\mathrm{H}^{+}$iontů.

Fig. 2: Evolution of aqueous components' stoichiometry during the experiment: Evolution of alkali elements' molar ratios to $\mathrm{Al}$ and $\mathrm{Si}(\mathrm{a})$; evolution of the increments/decrements of the equivalents of alkali elements and $\mathrm{H}^{+}$ions (b).

od 5,6 do 1,1. Při stechiometrickém rozpouštění by se tyto poměry měly blížit stechiometrii průměrného vzorku: $0,97(\{\mathrm{~K}+\mathrm{Na}+\mathrm{Ca}\} / \mathrm{Al}), 0,33(\{\mathrm{~K}+\mathrm{Na}+\mathrm{Ca}\} / \mathrm{Si})$ a $0,34(\mathrm{Al} / \mathrm{Si})$. Molární poměr $\mathrm{Al} / \mathrm{Si}$ (není na obrázku uveden) mírně rostl od 0,33 do 0,54 se značnými výkyvy během experimentu. Poměry v roztoku tak potvrzují přednostní uvolňování kationtů $\mathrm{AK} \& \mathrm{KAZ}$ před $\mathrm{Al}$ a Si ionty. Důsledkem je bezesporu vznik prrípovrchové vrstvy s pozměněným složením (vrstva je ochuzena o kationty). Existence této vrstvy byla prokázána jak při laboratorním zvětrávání (Hellmann et al. 1997), tak při přírodním zvětrávání (Zhu et al. 2006).

Z obrázku 2 b je zřejmé, že spotřeba vodíkových iontů je významně nižší než uvolněné ekvivalenty AK\&KAZ a neodpovídá tak předpokládanému poměru $1: 1$. Tento nesoulad je zmiňován i v dřivějších pracích (Casey et al. 1988; Hellmann et al. 1997). Modelování v programu PHREEQC ukazuje, že v otevřeném systému (v rovnováze s $\mathrm{CO}_{2}$ s parciálním tlakem $\mathrm{P}_{\mathrm{CO} 2} \sim 10^{-3,5}$ ) by se $\mathrm{pH}$ experimentálního roztoku mělo rychle zvýšit na hodnotu $\mathrm{pH}$ 7,2 s kolísáním v intervalu $\mathrm{pH} \sim 7,00-7,24$. V uzavřeném systému (který lze uvažovat v samých počátcích interakce, kdy je vliv $\mathrm{CO}_{2}$ zanedbatelný díky pomalé kinetice na rozhraní roztok-atmosféra) by $\mathrm{pH}$ roztoku mělo dosáhnout hodnot pH 10,49 (obr. 3). Porovnání s reálnými daty ukazuje, že v počátečních stádiích rozpouštění je naměřená hodnota $\mathrm{pH}$ nižší, než hodnoty $\mathrm{pH}$ teoretické jak v otevře- 


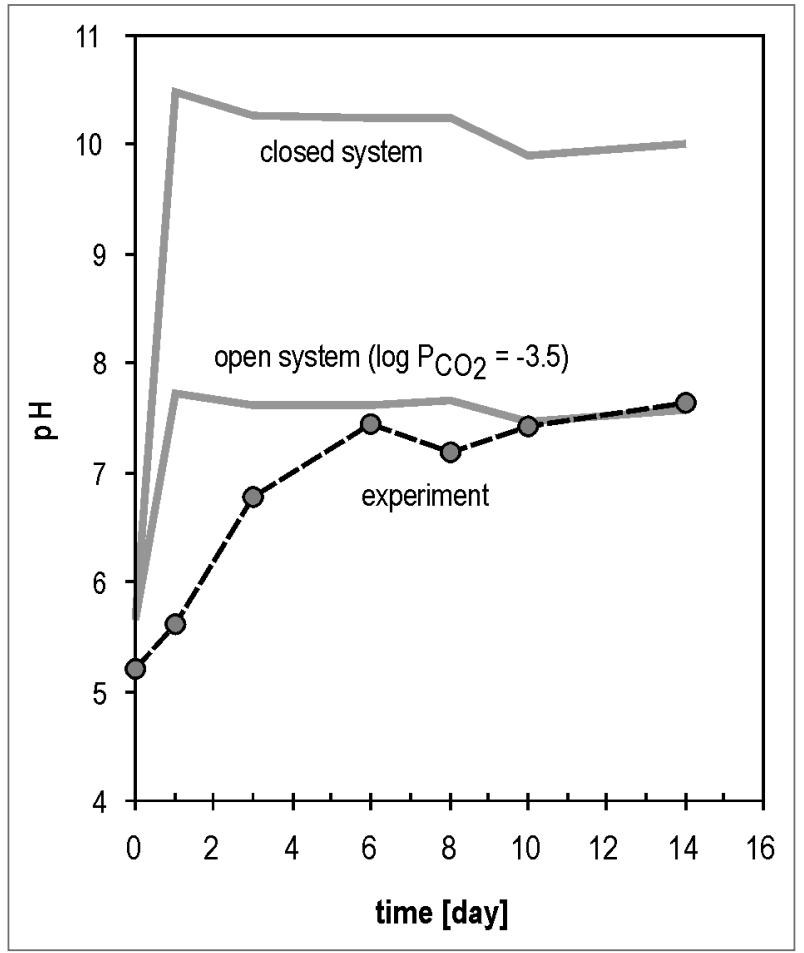

Obr. 3: Vývoj pH při interakci: porovnání experimentálních dat $\mathrm{s}$ modelovými hodnotami $\mathrm{v}$ uzavřeném a otevřeném systému $\left(\log \mathrm{P}_{\mathrm{CO} 2}=-3\right)$.

Fig. 3: Evolution of $\mathrm{pH}$ during feldspar-water interaction: comparison of experimental values with the values modeled for closed and open system $\left(\log \mathrm{P}_{\mathrm{CO} 2}=-3\right)$.

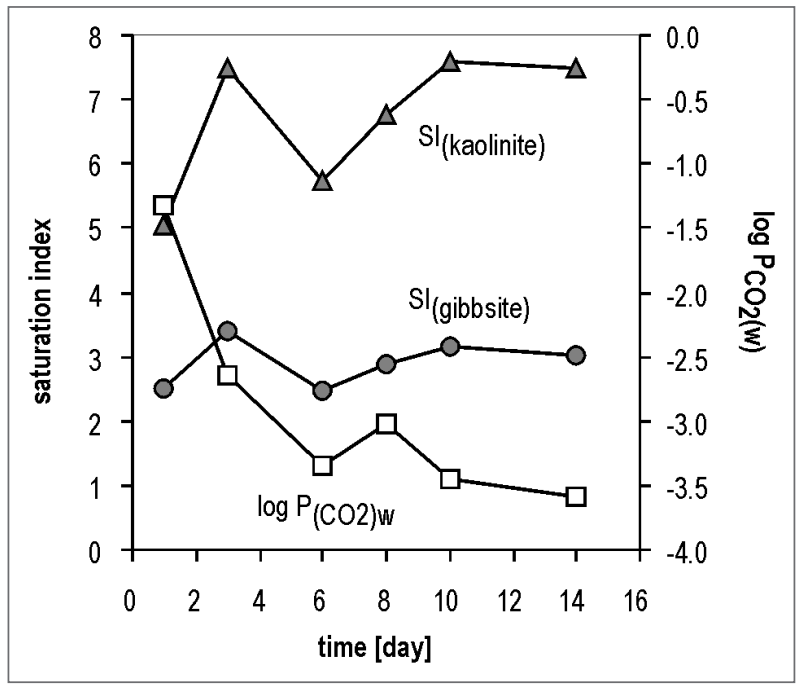

Obr. 4: Vývoj přesycení roztoku vybranými minerály a vývoj hypotetických parciálních tlaků $\mathrm{CO}_{2}$ odpovídající aktivitě karbonátových složek v roztoku během experimentu. Modelováno v programu PHREEQC s experimentálně určeným složením ( $\mathrm{pH}$ a koncentracemi vodných složek). Nábojová nerovnováha byla vyrovnána karbonátovými složkami.

Fig. 4. Evolution of solution saturation by selected minerals and evolution of the hypothetical $\mathrm{CO}_{2}$ partial pressures corresponding to aqueous carbonates during experiment. It was modeled under using of the PHREEQC code for experimentally determined data ( $\mathrm{pH}$ and aqueous component concentrations). The charge imbalance was corrected by aqueous carbonate species. ném, tak uzavřeném systému. $V$ dalších stádiích interakce (po 5. dnu experimentu) se $\mathrm{pH}$ experimentálních roztoků vyvíjí v blízkosti teoretických křivek odvozených pro otevřený systém. Za podmínky nábojové rovnováhy v roztoku by naměřená hodnota $\mathrm{pH}$ po prvním kroku interakce (1 den) odpovídala parciálnímu tlaku $\mathrm{P}_{\mathrm{CO} 2} \approx 10^{-1}$, který tak o dva a půl řádu převyšuje hodnotu v laboratorních podmínkách, $\mathrm{P}_{\mathrm{CO} 2} \approx 10^{-3,5}$ (obr. 4). To potvrzuje, že uvolněné množství alkalických iontů (ani celkové složení roztoku) neodpovídá změnám $\mathrm{pH}$.

Výpočty v programu PHREEQC naznačují značné přesycení roztoku gibbsitem a kaolinitem už v počátečních stádiích interakce (obr. 4), takže nelze vyloučit srážení sekundárních minerálů (přestože není př́liš pravděpodobné díky pomalé nukleační dynamice). Přímé prokázání srážení malého množství minerálů je technicky neproveditelné. Rekonstruovat tento proces ze složení roztoku je nemožné, vzhledem k předpokládanému nestechiometrickému rozpouštění primárních minerálů. Kromě toho, potenciální srážení sekundárních minerálů by nezměnilo bilanci spotřebovaných $\mathrm{H}^{+}$iontů a uvolněných kationtů, jak ukazují sumární rovnice pro hydrolýzu albitu v uzavřeném systému (2) a (3):

$$
\begin{aligned}
& \mathrm{NaAlSi}_{3} \mathrm{O}_{8}+\mathrm{H}^{+}+7 \mathrm{H}_{2} \mathrm{O}=\mathrm{Na}^{+}+\mathrm{Al}(\mathrm{OH})_{3(\mathrm{~S})}+ \\
& +3 \mathrm{H}_{4} \mathrm{SiO}_{4} \\
& \mathrm{NaAlSi}_{3} \mathrm{O}_{8}+\mathrm{H}^{+}+4,5 \mathrm{H}_{2} \mathrm{O}=\mathrm{Na}^{+}+ \\
& +0,5 \mathrm{Al}_{2} \mathrm{Si}_{2} \mathrm{O}_{5}(\mathrm{OH})_{4(\mathrm{~S})}+2 \mathrm{H}_{4} \mathrm{SiO}_{4}
\end{aligned}
$$

Výsledky studie tedy ukazují nesoulad mezi celkovým složením a pH experimentálního roztoku. Počáteční uvolnění $\mathrm{AK} \& \mathrm{~K} A Z$ neodpovídá jednoduché iontové výměně a vyžaduje sofistikovanější model. Nestechiometrické rozpouštění indikuje nezávislou hydrolýzu jednotlivých vazeb na povrchu živce. Díky vyšší polarizaci vazeb $\mathrm{Na}-\mathrm{O}, \mathrm{K}-\mathrm{O}$, a Ca-O dochází $\mathrm{k}$ jejich rychlejší hydrolýze v porovnání $\mathrm{s}$ vazbami $\mathrm{Al}-\mathrm{O}$ a zejména $\mathrm{Si}-\mathrm{O}$ a k prednostnímu uvolnění kationtů alkálií. Kvantitativní popis pokročilejších stádií rozpouštění vyžaduje 3-D model, který by zohlednil nejen reakce na povrchu, ale i postup hydrolýzy s časem směrem do „hloubky“ primárního minerálu.

\section{Závěr}

Tato práce byla zaměřena na lepší pochopení mechanismu interakce živec-voda. V rámci laboratorních experimentů byly rozpouštěny vzorky perthitického živce $\mathrm{v}$ deionizované vodě $\mathrm{v}$ míchaném vsádkovém reaktoru otevřeném atmosfére za normální teploty a tlaku. Výsledky ukazují, že rozpouštění během počátečních stádií interakce není stechiometrické. Vysoké molární poměry $(\mathrm{Na}+\mathrm{K}+\mathrm{Ca}) / \mathrm{Al}$ a $(\mathrm{Na}+\mathrm{K}+\mathrm{Ca}) / \mathrm{Si}$ dosažené v počátečních stádiích dokladují přednostní uvolňování kationtů alkálií do roztoku. Hodnoty $\mathrm{pH} \mathrm{v}$ počátečních etapách interakce byly významně nižší, než by odpovídalo množství uvolněných kovů. Modelování ukázalo, že parciální tlaky $\mathrm{CO}_{2}$, které by odpovídaly/vysvětlovaly dané $\mathrm{pH}$, převyšují o dva řády hodnoty obvyklé v laboratoři. Vývoj $\mathrm{pH}$ v mírně pokročilých stádiích experimentu kopíroval podle očeká- 
vání reakční cestu v otevřeném systému. Nesoulad mezi uvolněnými kovy a spotřebovanými $\mathrm{H}^{+}$ionty (1) indikuje že počáteční stadia interakce živec-voda neodpovídají jednoduché iontové výměně a (2) naznačuje mnohem složitější mechanismus.

\section{Poděkování}

Práce byla vypracována s institucionální podporou MU. Autoři děkují J. Zemanovi z ÚGV za podnětné připomínky.

\section{Literatura}

Appelo, C. A. J. - Postma, D. (2005): Geochemistry, Groundwater and Pollution, $2^{\text {nd }}$ edition. - A. A. Balkema Publishers, Leiden. Casey, W. H. - Westrich, H. R. - Arnold, G. W. (1988): Surface chemistry of labradorite feldspar reacted with aqueous solutions at $\mathrm{pH}=2,3$, and 12. - Geochimica et Cosmochimica Acta 52, 2795-2807.

Chou, L. - Wollast, R. (1985): Steady-state kinetics and dissolution mechanisms of albite. - American Journal of Sciences 285, 963-993.

Dougan, W. K. - Wilson, A. L. (1974): Absorptiometric determination of Al in water - comparison of some chromogenic reagents. - Analyst 99, 413-430.

Hellmann, R. - Dran, J. C. - Della Mea, G. (1997): Characterization of leached and hydrogenenriched layer formed at $300{ }^{\circ} \mathrm{C}$ using MeV ion beam techniques. - Geochimica et Cosmochimimica Acta 61, 1575-1594.

Parkhurst, D. L. - Appelo, C. A. J. (1999): User's guide to PHREEQC (Version 2): A computer program for speciation, batch-reaction, one-dimensional transport, and inverse geochemical calculations. - U. S. Geological Survey. Water-Resources Investigations Report 99-4259, 1-312.

Truesdale, V. W. - Smith, C. J. (1976): The automatic determination of silicate dissolved in nature fresh water by means of procedures involving the use of either $\alpha$ - or $\beta$-molybdosilicic acid. - Analyst 101, 19-31.

Zhu, C. - Veblen, D. R. - Blum, A. E. - Chipera, S. J. (2006): Naturally weathered feldspar surfaces in the Navajo Sandstone aquifer, Black Mesa, Arizona: Electron microscopic characterization. - Geochimica et Cosmochimica Acta 70, 4600-4616. 